Georgia State University

ScholarWorks @ Georgia State University

8-2-2019

\title{
Mission to Planet Markle: Problem-Based Learning for Teaching Elementary Students Difficult Content and Practices
}

\author{
Melanie Peffer \\ University of Colorado, Boulder \\ Maggie Renken \\ Georgia State University \\ Patrick Enderle \\ Georgia State University \\ Jonathan Cohen \\ Georgia State University
}

Follow this and additional works at: https://scholarworks.gsu.edu/ltd_facpub

Part of the Instructional Media Design Commons

\section{Recommended Citation \\ Peffer, Melanie; Renken, Maggie; Enderle, Patrick; and Cohen, Jonathan, "Mission to Planet Markle: Problem-Based Learning for Teaching Elementary Students Difficult Content and Practices" (2019). Learning Sciences Faculty Publications. 25. \\ https://scholarworks.gsu.edu/ltd_facpub/25}

This Article is brought to you for free and open access by the Department of Learning Sciences at ScholarWorks @ Georgia State University. It has been accepted for inclusion in Learning Sciences Faculty Publications by an authorized administrator of ScholarWorks @ Georgia State University. For more information, please contact scholarworks@gsu.edu. 


\section{Running Head: PROBLEM-BASED LEARNING OUTCOMES}

2

3

4

5

6

7

8

9

10

11

12

13

14

15

16

17

18

19

20

21

22

23

24

25

26

27

28

29 


\begin{abstract}
Young children can struggle to learn difficult disciplinary content and important skills for practicing science. Problem-based learning (PBL) may be useful for addressing such difficulties, yet evidence to support its usefulness in elementary school-aged children is limited. We considered the role of a PBL unit in improving students' genetics content understanding and their skills specific to creating arguments with coordinated claims, evidence, and reasoning. Firstthrough fifth-grade students participated in a six-week PBL unit about evolution and genetics. Students worked in mixed age groups and were charged with illustrating a fictitious alien species, called markles, based on a series of facts they collected about factors expected to impact markle adaptation. This work was particularly unique in its assessment of student groups' illustrated design solutions as arguments. Although students demonstrated weaknesses in coordinating claims and evidence overall, they were able to demonstrate success in gaining difficult genetics content knowledge and in preparing arguments with, at minimum, two components of well-constructed arguments, in most cases, providing a claim supported by reasoning. This work is informative for understanding student abilities, the potential of PBL, and considerations for its use.
\end{abstract}

Keywords: Problem-based learning, genetics education, argumentation, elementary science education 
Mission to Planet Markle: Problem-Based Learning for Teaching Elementary Students Difficult Content and Practices

Problem-based learning (PBL) is a learner-centered approach to instruction. In a PBL

58 context, the learner develops a solution to a defined problem through research and the

59 application of his or her knowledge and skills (Savery, 2015). PBL has been touted for its

60 effectiveness in garnering a host of education-relevant outcomes across disciplines. By engaging

61 students in practical, experiential learning, a PBL approach in science disciplines is expected to

62 foster students' general science practices and discipline-specific content knowledge in tandem

63 (Dochy, Segers, Van den Bossche, \& Gijbels, 2003). Such an approach is in line with $A$

64 Framework for K-12 Science Education and the derivative Next Generation Science Standards

65 (NGSS), which emphasize the value in coordinating students' development of science practices

66 and core content knowledge acquisition (NGSS Lead States, 2013; National Research Council,

67 2012).

In a thorough review of what and how students learn via PBL, Hmelo-Silver (2004)

69 provides evidence of PBL's effectiveness in advancing students' knowledge base, problem

70 solving skills, and self-directed learning skills following problem-based learning experiences.

71 Unfortunately, a shortage of empirical evidence of what students learn in PBL settings remains

72 despite Hmelo-Silver's acknowledgment of as much over ten years ago. The dearth of evidence

73 is particularly noticeable in K-12 settings (cf. Wirkala \& Kuhn, 2011). The domains of learning

74 best supported by PBL in Hmelo-Silver's seminal 2004 review neatly align with three broad

75 domains of learning we consider to serve as holistic science learning in the current study:

76 content knowledge, science practices, and $21^{\text {st }}$ century skills. Namely, we examined PBL

77 outcomes related to content knowledge in a genetics domain and the scientific practice of 
argumentation (Kereluik, Mishra, Fahnoe, \& Terry, 2013; Voogt \& Roblin, 2012). Prior research

has suggested these outcomes may be fostered with PBL. We build on this prior work

predominately examining the utility of PBL for older students by considering outcomes of PBL associated with elementary school-aged children. The current study aims to contribute empirical support for incorporating PBL in elementary science curriculum.

\section{PBL for teaching difficult genetics content knowledge}

PBL use in the classroom, and especially in the K-12 science classroom, abounds (Walker, Leary, Hmelo-Silver, \& Ertmer, 2015). Presenting students with ill-structured problems with no single path of inquiry provides students the opportunity to collaboratively assess data provided, refine their ideas, and experience the tenuous nature of science knowledge by deciding on a solution that may not be correct (Gallagher, Stepien, Sher, \& Workman, 1995). The popularity of PBL as a pedagogical approach may be due to its expected ability to engage students in learning difficult content. One such challenging content area for school-aged students is genetics. For instance, an analysis of genetics themed essays written by high school students indicated the prevalence of many misconceptions (Shaw, Van Horne, Zhang, \& Boughman, 2008). This is particularly concerning since before the Next Generation Science Standards, genetics education began in middle school (National Research Council, 1996) and now begins in elementary school (NGSS Lead States, 2013). In spite of years of instruction in genetics, these misconceptions persist. Children are introduced to terms such as "genes" and "genetic inheritance" passively from the entertainment industry but are unsure what those terms mean (Venville, Gribble, \& Donovan, 2005), and such exposure may foster misconceptions that persist through high school, stunting potential genetic understanding gains (Smith \& Williams, 2007). Work by Duncan and Reiser (2007) suggests that part of the difficulty with learning genetics is due to challenges 
102 associated with reconciling information across different levels, such as how what is occurring at

103 the DNA level impacts what is occurring at the protein level in a cell. Even at the undergraduate

104 level, students do not understand how features are inherited, for example believing that diseases

105 are inherited from biological parents, rather than from genetic material (Henderson \& Maguire,

106 2000).

107 Genetics may be learned best in the context of inquiry (Duncan, Rogat, \& Yarden, 2009).

108 Previous work demonstrated that genetics-themed PBL units were more effective than direct

109 instruction for increasing eighth-grade students' understanding of genetics content (Araz \&

110 Sungur, 2007). Although evidence suggests such instruction is effective for improving students'

111 understanding of genetics, the majority of interventions are designed for high school students,

112 with significantly fewer for middle school and late elementary school (Duncan et al., 2009).

113 Previous work suggests that later elementary-aged students are familiar with the concepts of

114 genetic inheritance (Springer \& Keil, 1989), and a learning progression proposed by Elmesky

115 (2013) suggested that curricula should leverage the cognitive abilities of K-5 students to develop

116 a more advanced theory of kinship and genetic inheritability to lay the foundation for

117 understanding gene expression in later grade levels. Similarly, a learning progression by Duncan

118 et al. (2009) proposed fifth- and sixth-grade students should have a basic understanding of

119 inheritance, traits, and DNA. In the 2007 National Research Council Report, Taking Science to

120 School: Learning and Teaching Science in Grades K-8, the authors conclude that all children,

121 even very young children, are capable of engaging in complex reasoning about the world. This is

122 reflected in the NGSS as genetics content appears in the third-grade standards (NGSS Lead

123 States, 2013). Consequently, interventions and research geared toward genetics learning for

124 students in elementary school, particularly in early grades, are necessary. 


\section{Young students' arguments: Coordination of claims, evidence, and reasoning}

Beyond promoting acquisition of difficult content knowledge, PBL has been traditionally employed to foster important science practices (Allen, Duch, \& Groh, 1996; Baser, Ozden, \& Karaarslan, 2017; Bell, 2010; Ferreira \& Trudel, 2012; Kolodner et al., 2003; Kwon et al., 2018). For example, in the context of clinical education, medical students who engaged in PBL exhibited enhanced clinical problem solving ability (Savery, 2015). PBL activities can often conclude with students making a final argument in response to the initial ill structured problem (Belland, Glazewski, Richardson, 2011). Argumentation is widely recognized as a critically important practice in science education (Berland \& Reiser, 2009; McNeill \& Krajcik, 2006; National Research Council, 2012; Ryu \& Sandoval, 2012). The ability to engage in arguing from evidence is one of eight core science and engineering practices described in the NGSS (NGSS Lead States, 2013). According to the NGSS, students in elementary school should be able to identify arguments and what makes an argument "good," particularly with regard to evidence. The standards also state that both early and late elementary school students are expected to be able to use evidence to construct an argument. Teaching students about and through argumentation alongside science content accomplishes multiple curricular goals. When engaged in argumentation and the creation of arguments, students apply content knowledge, engage productively in written and verbal discourse, and begin to understand that science is not a discrete collection of facts, but rather a body of knowledge generated through various discursive and cognitive activities (Manz, 2015). Argumentation encourages science learning as a vehicle for making sense of the world, as opposed to a passive student experience (Berland, Schwarz, Krist, Kenyon, Lo, \& Reiser, 2015). Research has shown, though, that argumentation and the creation of arguments is challenging for elementary school students (McNeill, 2011; Ryu \& 
148 Sandoval, 2012) and middle school students (Belland, Glazewski, Richardson, 2011). In

149 particular, teaching students to support claims with evidence-a key component of scientific

150 arguments - has proven to be a challenge for science educators (Berland \& Reiser, 2009).

151 Limitations associated with students' writing and discourse abilities contribute to challenges in

152 helping students learn to support claims with evidence and in assessing students' ability to do so

153 (Felton, 2004; Sampson, Enderle, Grooms, \& Witte, 2013).

154 Despite its status as an important and widely accepted part of science education, creating

155 high quality arguments remains difficult for students to learn. Prior research has examined the

156 nature of some of students' difficulties and the impact of curriculum on them (e.g., McNeill,

157 2009; Osborne, Erduran, \& Simon, 2004). McNeill (2011) analyzed fifth-grade students' written

158 arguments over the course of a school year. Student writing was analyzed to determine if it was

159 argumentative in nature and if it contained arguments in a claim, evidence, reasoning format.

160 Overall, students' argument construction improved over the course of the school year, but when

161 given challenging content, students struggled to make accurate and appropriate arguments.

162 Interviews with participating students revealed that while their overall ability to write scientific

163 arguments had improved, the students still lacked an understanding of the importance of using

164 evidence to support claims (McNeill, 2011). Prior work has demonstrated that, at least by middle

165 school, curriculum that highlights argument components (i.e., claim, evidence, and reasoning)

166 aids students in their ability to ground arguments in evidence (Berland \& Reiser, 2009; McNeill

167 \& Krajcik, 2006). Berland and Reiser's (2009) analysis of middle school students' written

168 arguments revealed two main categories: arguments that explicitly reference evidence and

169 arguments that implicitly reference evidence. The overall ability of students to make high quality 
170 arguments explicitly incorporating evidence requires more attention and guidance (Berland \& 171 Reiser, 2009).

172 Similarly, Ryu and Sandoval (2012) examined third- and fourth-grade students' argument

173 construction over a period of a school year. Students were engaged in a science curriculum in

174 which their teacher prompted students working in groups to justify how they know something or

175 how they would convince others of what they know. Ryu and Sandoval (2012) assessed

176 arguments based on students' use of causal claims, the coherence of claims, citation of evidence,

177 and whether or not the student explicitly justified their argument. The authors noted

178 improvement over the school year in the students' ability to relate claims to each other in a

179 coherent manner, their ability to cite evidence, and the use of explicit justification. These

180 developments were attributed to explicit and consistent guidance offered to students through

181 expectations for arguments that were communally established among teachers and students.

182 Although improved, students' ability to explicitly justify their claims with data was still lower

183 than the other aspects of argumentation examined in the study (Ryu \& Sandoval, 2012). These

184 studies, as well as others in the argumentation literature (Sampson \& Clark, 2008), demonstrate

185 students' challenges with respect to explicitly supporting claims with evidence in written

186 arguments, especially in classroom settings. Further, challenges persist in the use of curricular

187 interventions to help students with connecting claim and evidence (McNeill \& Berland, 2017).

188 PBL activities are one type of curricular intervention that can foster productive

189 argumentation interactions (Belland, 2010). PBL frames instruction with a context, or issue,

190 requiring students to know and use relevant scientific information (Hmelo-Silver, 2004).

191 Students can use scientific information to lead an investigation or to design a solution. For

192 example, to create a PBL context that fosters productive argumentation, some PBL units revolve 
193 around a broad, investigable question that can lead to multiple productive investigations. Other

194 PBL units employ a problematic, ill-structured context, usually drawn from real world

195 circumstances, that necessitates the design of potential solutions (Householder \& Hailey, 2012).

196 Real world problems are typically messy, lacking the type of well-defined nature that often

197 mitigates students' motivation or engagement. The real-world context requires students to set

198 parameters and pull resources from a variety of disciplines (Savery, 2015). When framing a PBL

199 unit in the real-world context, students' endeavors change in nature from one focused on

200 conducting scientific investigations to the designing and refining of problem solutions. Although

201 both are emphasized in national standards (NGSS Lead States, 2013), the integration of design

202 challenges for the goal of enhancing science instruction remains problematic (Berland, 2013).

203 The argument products developed during design challenges must reflect the unique

204 purpose and kinds of reasoning used for designing a problem solution (Berland, 2013).

205 Theoretical frameworks of argumentation identify several commonly accepted or related

206 structural elements inherent in high quality arguments (Grooms, Enderle, \& Sampson, 2015;

207 McNeill \& Krajcik, 2006; Osborne et al., 2004; Sampson \& Clark, 2008). These frameworks

208 have mostly focused on the production of arguments from scientific investigations and not those

209 arguments that result from design challenges. The nature and characteristics of traditional

210 argument elements (e.g., claim, evidence, and reasoning) must shift to reflect the different

211 activity goal of achieving a problem solution that meets certain criteria and specifications.

212 The first argument element to consider is the claim, which is typically an assertion that

213 directly answers the question guiding a scientific investigation (McNeill, 2011). In design

214 challenges, the claim would comprise either a proposed concept from the initial stages that is

215 ideal for developing a prototype. Rather than the assertive statement typical for scientific 
216 arguments, the claim in a design argument can encompass a hypothetical schematic or a physical

217 model. When considering evidence in a design argument, a design activity shifts the type of

218 information analyzed to support the claim, focusing mainly on the constraints and criteria set

219 forth in the design problem (McNeill \& Krajcik, 2006). Finally, the reasoning element in a

220 design argument would involve statements that explain how the evidence used for a particular

221 stage supports the claim being made in that stage (Sampson \& Clark, 2008). For design

222 arguments, these statements would emphasize how elements of the prototype design (claim)

223 align with the constraints and criteria stemming from the design problem (evidence). In the

224 current study, we examined students' illustrated products at the end of a problem-based learning

225 unit for indication of three component parts of an argument: claim, evidence, and reasoning. One

226 of our research objectives was to determine if elementary students were able to support

227 illustrated claims with evidence.

Illustrated design solutions as arguments. When focusing on the ability to construct high

229 quality arguments, many studies have analyzed written text created through students' activities

230 (Berland \& Reiser, 2009; McNeill, 2011; Sampson et al., 2013). By assessing text-based

231 products, such research has shed light on students' understanding of specific science content and

232 the structural elements that make up scientific arguments. Further, written arguments serve as

233 proxies, representing students' proficiency with engaging in the process of arguing from

234 evidence (Sampson et al., 2013). However, written text is not the only manner available for

235 students to express an argument composed of claims, evidence, and reasoning.

236 Drawings and graphic representations, compared to text-based forms, are considered to

237 be equally valid products for assessing students' understanding of complex systems and

238 phenomena (Bowker, 2007; Dentzau, in press; Lewis \& Greene, 1983; White \& Gunstone, 
1992). Scholars have argued that using drawings can make students' conceptions more

240 accessible due to the perception of drawing as being a less intimidating, and often enjoyable,

241 activity compared to writing, particularly for younger students (Chang, 2012; Thomas \& Silk,

242 1990). Chang (2012) contends that drawings are also applicable for assessment purposes with

243 small groups of children as well as with individuals. Thus, allowing young students to generate

244 drawings to represent conceptual understanding can also provide a way to decrease apprehension

245 related to learning relatively complex science content, such as genetics. Also, having students

246 draw the representations of different argument components could provide another vehicle for

247 conveying the importance of individual components and relationships between them.

\section{Current Study}

The driving question of the current study was whether PBL supports gaining content

250 knowledge and science practices. The PBL unit utilized for this study introduced students to the

251 concepts of genetics and evolution and concluded with a capstone argument design project.

252 Given that we know very little about PBL to teach genetics and develop arguments at the

253 elementary school level, we sought to preliminarily examine each individually. We assessed

254 student genetics understanding at the beginning and end of the unit using a pre/posttest format.

255 To assess students' ability to create arguments, we asked student groups to create a capstone

256 argument design project to complete a PBL unit that removed writing demands, the potential

257 impact of prior belief bias, and the possibility of a correct answer. Students were instructed to

258 generate a creative, illustrated product rather than a written argument. We hypothesized that

259 asking students to generate drawings rather than written arguments would make generating

260 arguments supported by evidence more accessible to elementary school students. In other words,

261 we expected to observe evidence-based claims in student groups' collaborative illustrations. 


\section{Methods}

Participants

The participants in this study were 80 elementary students in grades 1 through 5 at a Title I elementary school located in a suburb of a large southeastern city (Table 1). Title I schools contain a significant proportion of children from low socioeconomic status families and receive federal funding to help children meet state and academic standards. $57 \%$ of the students at the participating elementary school were below the poverty line. At the time of this study, schools implemented grade-appropriate Georgia Performance Standards (GPS) as the measure of benchmarks for all academic subjects, but in 2016 the Georgia State Board of Education approved a new set of standards titled the Georgia Standards of Excellence (GSE) for schools to adopt during the 2017-2018 school year (Georgia Department of Education, 2015).

Table 1. Grade distribution of Participating Students

\begin{tabular}{l|cc}
\multicolumn{2}{c}{$n$} & \% of Total \\
\hline First Grade & 10 & $12.5 \%$ \\
Second Grade & 16 & $20 \%$ \\
Third Grade & 21 & $26.3 \%$ \\
Fourth Grade & 11 & $13.8 \%$ \\
Fifth Grade & 22 & $28 \%$
\end{tabular}

All 80 students participated in the PBL unit and design argument assessment. Data used for the genetics knowledge assessment involved only the 67 students who were present in school during both the pre and posttest. These 67 students were comprised of 9 first graders (13\%), 10 second graders (15\%), 17 third graders (25\%), 11 fourth graders (16\%) and 20 fifth graders 
280 (30\%). Students participating in this study were a mix of talented-and-gifted (TAG) and able 281 learners (i.e., students above grade level on a measure of math or reading ability, or both).

282 During the daily enrichment period, (see intervention procedure below), TAG and able learners

283 engaged in PBL with the school gifted coordinator and support staff including the media

284 specialist, art teacher, math coach, and counselor. Participants were $52.6 \%$ female and $46.2 \%$

285 male. One student declined to identify gender. We did not collect race/ethnicity data, but the

286 school district of the participating school is $48 \%$ African-American, $37 \%$ Caucasian, $8 \%$

287 Hispanic, 4\% Multi-racial and 3\% Asian.

288 Unit design and intervention procedure

The intervention took place over six weeks during the daily enrichment period at the

290 research site school. The enrichment period took place from Tuesday to Thursday for 45 minutes 291 a day in the school media center. During this window of time, students school-wide were moved

292 to classrooms or school sites that were not their homerooms for remedial or enrichment time.

293 Students who participated in the study were assigned to enrichment rather than remediation 294 support. This was the third PBL unit students in this group had participated in during the school 295 year, but it was the first unit focused on biology learning. Enrichment period PBLs were 296 designed to align with specific standards that would be addressed in the students' homeroom 297 class for a deeper level of engagement. During all PBL units, students worked collaboratively 298 around a central theme or question. The first PBL unit that students engaged in was a school 299 courtyard redesign project. Students worked in groups to design the space and create a budget for 300 the redesign. Their final projects were presented to a board of community stakeholders and 301 school staff. The second PBL unit was focused on students using scientific reasoning skills to 302 solve a mystery, namely why a farmer's chickens stopped laying eggs. Students were divided 303 into 16 mixed-age groups, with 6-7 students in each group. Students from each grade level were 
304 represented within each group, but distribution varied. Each day, the student groups worked 305 through a PBL activity related to genetics and evolution, specifically on animal adaptations.

306 Under the Georgia Performance Standards, approved in 2004, animal adaptations in relation to

307 the environment are introduced as a framework in the first grade; each grade builds on that

308 foundational understanding, but genetics is not included as a distinct unit until the fifth grade.

309 Additionally, these standards identify science communication through writing and drawing as a

310 key competency starting in the first grade and introduce scientific argumentation in the third

311 grade (Georgia Department of Education, 2015). Under the new Georgia Standards of

312 Excellence, the content areas are identical to the previous standards, but the focus has shifted to

313 more inquiry-based instruction.

314 To start the PBL unit, students were introduced to a fictional scenario in which a group of

315 scientists were dispatched to study organisms called markles, who live on a planet far out of the

316 solar system, Planet Markle. However, the scientists in the scenario are concerned that the

317 markles may evolve and consequently change their appearance during the extended time period

318 of travel from Earth to Planet Markle. Therefore, students were placed in the role of Mission

319 Planners. As Mission Planners, they hypothesized about the appearance of the markles and

320 devised plans for capturing the creatures, based on information on basic genetics principles

321 presented earlier at a series of stations as part of the PBL unit, information provided about the

322 markles' home planet, and the students' own claims about the markles' appearance, respectively.

323 Although fictional, the problem space mimicked that of a real world context. It lacked a rigid and

324 clearly-defined problem space and required students to use information from a variety of sources.

At the beginning of the unit, students were instructed to visit stations to learn how

326 animals on Earth change their appearance over time. Each of the four stations had its own 
327 learning objectives, questions to answer, and after completing the station, students earned a 328 factoid (Table 2) related to both their station and fictional markle biology. The first station was 329 titled "Genes, Environment, and Phenotypes: Why do we look the way we do?" and introduced 330 students to the concept of cells containing DNA, the hereditary nature of DNA, and how both

331 DNA and the environment can influence our phenotype, or how we look. Students completed the

332 Dragon Genetics simulation to model how genes influence phenotype, and how this information 333 is passed between parents and offspring. Students also learned about how heat influences the 334 coat color of Siamese cats. The second station, "Adaptations," introduced students to the concept 335 of adaptations, gave examples of adaptations, (e.g., long necks on giraffes), and described how 336 adaptations can form over time due to evolutionary forces (e.g., Galapagos finches). The third 337 station was titled "Mutations and Survival" and introduced students to mutations (changes in 338 DNA), and how mutation can lead to new adaptations and evolution. Students explored the 339 relationship between mutation and color in pepper moths using an online lesson and 340 accompanying game (peppermoths.weebly.com). The final station, "Genetic Drift and Natural

341 Selection," explored how different processes influence the number of genes that are available

342 impact a species. Students learned about extinction, non-random selection of genes (natural and 343 artificial selection), and random removal of genes via genetic drift. Students played a game 344 developed by the first author to demonstrate natural selection and genetic drift. For the natural 345 selection demonstration, students took several butterflies and were told that they represented the 346 total population of butterflies in a backyard. Some butterflies contained lots of decoration 347 whereas others were plain. Students then selected half of the butterflies to go into their private 348 collection, and then discussed how removal of those particular butterflies changed the diversity 349 of phenotypes, and consequently genes present in the population. During the second part of the 
350 demonstration, students removed 20 numbered beetles from a bag, half green and half orange.

351 Students first counted how many of each type of beetle was present and wrote it in their

352 notebook. Then students rolled a 20 -sided die five times. If a beetle's number was selected, it

353 was turned over and considered dead. Students then counted how many orange and green beetles

354 were left after some were randomly removed from the population. This process was repeated at

355 least once more and numbers compared to demonstrate the random impact on the population.

356 Upon completion of each station's activities, students earned a sticker with a factoid relevant to

357 markle adaptations. A list of factoids collected at each station is in Table 2.

358 After students completed all of the stations, they were randomly assigned features of a

359 particular region of Planet Markle. Examples of these features are shown in Table 3. Based on

360 these features, students drew what they thought the markles in their region would look like.

361 Students also were told to design a trap to capture the markle based on their predictions of the

362 creatures' appearance and behavior. Each student group prepared a presentation during which

363 students described their markle and their plan for trapping the markle. To support their

364 presentations, students prepared notecards with details about the markle and trap design.

365 Students received no instruction on argumentation or scientific explanation.

366 Unscripted scaffolds were provided by the five instructors present during instructional

367 focus time and by the series of stations at which students learned genetics principles. The first

368 author assessed fidelity of curriculum implementation by visiting the school site once a week to

369 observe the unit. The first and second authors attended the students' concluding presentations to

370 make observations and to collect student artifacts, including the groups' illustrations and notes. 
Table 2. The factoids students earned upon completing each station. The students integrated

these factoids into their final markle drawings.

Station Factoid

Genes, Environment, and Phenotype

Markles inherit different genes from their parents. Since these genes lead to certain phenotypes, if a markle has one parent with spotted fur (and the gene for spotted fur), they will also have spotted fur. When a markle is born, it is light colored. If the markle grows up in a cold climate, it will eventually be blue. Their blue color helps them blend in with the water, so blue markles tend to live near water and eat fish. Markles that grew up when it is warmer are green and live in the trees where they can blend in better with their surroundings. Markles want to blend in with their surroundings so other animals do not eat them.

Adaptations Markles have different adaptations that they use to find food, escape predators, and have babies. These adaptations include big noses, long legs, long hair to help camouflage and keep the markle warm, wings for flying, snorkels, and suction cup hands. Big noses and snorkels help the markles find food. Without the snorkels, markles can't go fishing for food. Their big noses help the markles sniff out food and without them, they would be limited to only using their eyes to look for food. Giant bears can eat markles. The giant bears are slow and because of their size, can't climb trees to chase after the markles. Therefore, if a markle has adaptations such as wings, long legs or suction cup hands for climbing the markle is more likely to get away. Without these adaptations, the markle relies on camouflaging behind its long hair, or its color. Remember, much like the finches we learned about in this station, although all markles are similar, they have different adaptations depending on their specific environment. As the markles' environment changes over the time it takes for our astronauts to arrive, the markles' adaptations will also change.

Mutations and Some markles will be albino (all white) because of a random mutation. Being albino can be good Survival or bad depending on whether there is lots of snow on the ground or not since the markle can hide better on a white background. If there is no snow on the ground, the albino markle can't hide easily and is more likely to be eaten by predators.

Genetic Drift and There are many volcanoes on Planet Markle. These volcanoes can kill markles that get stuck in Natural Selection the lava flows. The volcanoes can also spread ash everywhere turning all of the trees from green to white. Some markles have spots on their fur. Next to Planet Markle is a planet where a species of aliens called narps. Narps love to wear spotted markle fur and hunt spotted markles for their fur.

of Planet Markle features they received. 
Your region is very cold.

Your region of Planet Markle is very dark and it is difficult to find food using eyesight alone.

Your region of Planet Markle has large cliff faces. Birds like to nest high on these cliff faces, and markles love to eat their eggs.

Your region is susceptible to tidal waves and markles are at risk for drowning without certain adaptations.

Your region is in a desert with lots of quicksand.

Data collection and analysis

We collected data associated with our primary research questions, including students' genetics content knowledge and illustrated design arguments. Content knowledge was collected 386 at the individual level, while illustrated design arguments were completed in groups. students in high school (Shaw et al., 2008). Since these misconceptions persist and may begin in 389 the early elementary grades (Smith \& Williams, 2007) we decided to focus our assessment on 390 these common misconceptions, rather than a comprehensive assessment of everything learned 391 during the PBL unit. In order to determine if engagement in PBL resulted in enhanced 392 understanding of these particularly difficult to understand genetics concepts, we asked students 393 to do a pre/posttest assessment of their understanding of two of domains of these common 394 misconceptions: (1) the deterministic nature of genes and (2) the nature of genes and genetic 395 material. We asked students two questions related to the deterministic nature of genes: Why do 396 people look different from each other? Why don't all people have the same hair color? We asked 
397 students one question about the nature of genes and genetic material: What are genes? The three

398 items were open ended. Students answered the items at the beginning and end of the PBL unit.

399 We removed data from students who were absent during either the pre or posttest. Sixty-seven

400 students participated in both the pretest and posttest.

401 Student responses were blinded and then coded by two researchers on a scale of $0-4$,

402 where $0=$ no response and $4=$ mature understanding. A summary of the rubrics used is shown in

403 Table 4. When coders disagreed, a third researcher served as the tiebreaker. Interrater reliability

404 for this coding was acceptable for all three questions (Question 1, Cohen's kappa = 0.92;

405 Question 2, Cohen's kappa =0.93; Question 3, Cohen's kappa $=0.81$ ).

Table 4. Rubric for coding students' responses to genetics assessment items.
Score
Questions 1 and 2
Example
Question 3
Example

Answer

Answer

\begin{tabular}{|c|c|c|c|c|}
\hline 0 & \multicolumn{2}{|l|}{$\begin{array}{l}\text { No response, } \\
\text { illegible, un- } \\
\text { intelligible or "I don't } \\
\text { know" }\end{array}$} & \multicolumn{2}{|l|}{$\begin{array}{l}\text { No response, } \\
\text { illegible, un- } \\
\text { intelligible or "I don't } \\
\text { know" }\end{array}$} \\
\hline 1 & $\begin{array}{l}\text { No attempt at } \\
\text { explanation, restates } \\
\text { the question }\end{array}$ & $\begin{array}{l}\text { People weren't } \\
\text { born the same }\end{array}$ & $\begin{array}{l}\text { Mentions } \\
\text { characteristics } \\
\text { controlled by genes } \\
\text { such as skin or hair } \\
\text { color. No mention of } \\
\text { parents, inheritance, } \\
\text { or DNA. }\end{array}$ & $\begin{array}{l}\text { Genes are a type } \\
\text { of animals like } \\
\text { cats. All cats are } \\
\text { in the same } \\
\text { genes }\end{array}$ \\
\hline 2 & $\begin{array}{l}\text { Non-biological } \\
\text { explanation (God, } \\
\text { ethnicity, culture) }\end{array}$ & $\begin{array}{l}\text { Because God } \\
\text { made them that } \\
\text { way }\end{array}$ & $\begin{array}{l}\text { Describes genes as } \\
\text { cells or traits. No } \\
\text { mention of } \\
\text { heritability. }\end{array}$ & $\begin{array}{l}\text { Genes are things } \\
\text { in your body that } \\
\text { give you } \\
\text { characteristics }\end{array}$ \\
\hline 3 & $\begin{array}{l}\text { Biological } \\
\text { explanation that } \\
\text { includes } \\
\text { understanding of } \\
\text { family, parents, or }\end{array}$ & $\begin{array}{l}\text { Our parents did } \\
\text { not look the } \\
\text { same so we are } \\
\text { most likely not }\end{array}$ & $\begin{array}{l}\text { Mentions concepts of } \\
\text { inheritance, but does } \\
\text { not fully explicate } \\
\text { what genes are. } \\
\text { Describes genes as }\end{array}$ & $\begin{array}{l}\text { Genes are things } \\
\text { that are passed } \\
\text { on from your } \\
\text { parents }\end{array}$ \\
\hline
\end{tabular}


inheritance. Does not to look the same traits or generic

mention genes as our parents "things" that come

\section{Explicitly mentions} genes, genetics, inheritance

People look
different from
one another
depending on the genes they receive from their parents from parents.

Explicitly mentions Genes are the DNA. Makes DNA in your connection between body that determines who relationship to parent. you are and what you look like

Design argument assessment. We collected group-generated design drawings and

411 supporting presentation notecards for data analysis. Notecards contained details about illustrated

412 markles and traps that students felt were most important to their presentations. Students received

413 no direct instruction regarding what information to include on their notecards. Brooks (2009)

414 contended that one of the strengths of using drawings for students to express their understanding

415 lies in the ongoing facilitation of dialoguing in other modes (such as writing) that help students

416 explore complex ideas. In light of this connection, we chose to include the presentation notecards

417 in the argument analysis in an attempt to fully capture student groups' use of evidence and

418 reasoning in their design solution. Final products were evaluated by assessing the presence of

419 claims, evidence, and reasoning elements in the drawings and notecards.

$420 \quad$ Being a design challenge, we analyzed students' work using adapted conceptualizations

421 of argument components (claim, evidence, reasoning) (McNeill \& Krajcik, 2006) better suited

422 for design challenges as opposed to scientific investigations. Broadly speaking, these three

423 elements of written arguments provide different kinds of information to a reader. The claim is an

424 answer to the problem or question posed in a particular context (Sampson, Enderle, \& Grooms,

425 2013). Although, structurally, the claim is typically provided first, these answers are ultimately 
426 derived from the evidence generated during an investigation or development of a problem

427 solution (Sampson et al, 2013a). Evidence in scientific arguments entails the data and

428 information that has been analyzed and interpreted, involving the identifications of trends,

429 patterns, comparisons, and contrasts. The reasoning component of an argument involves making

430 connections between the claim and evidence using design principles and scientific concepts

431 (Sampson et al, 2013a).

432 With respect to claim in the Markle design challenge, the groups' markle drawing was

433 considered to be the overarching claim as it represented the actual solution to the design

434 challenge embedded in the PBL unit. Specific features of the markle highlighted in the drawings

435 or notecards were also considered as claims. We characterized evidence as the environmental

436 constraints, in the form of factoids or Planet Markle features, provided to the student groups

437 during the unit. For evidence to be considered present in the groups' design arguments, either

438 explicit drawings of the environmental elements described in the factoids or features, or explicit

439 statements describing them in the notecards had to be included. Although we do see instances

440 where students choose features directly from the factoids, this is not always the case. It is likely

441 that reasoning occurred at different levels, with some creative ventures pursued while the

442 factoids are utilized generally. Finally, reasoning elements included drawings or statements that

443 connected particular features of the markle to the environmental constraints identified by each

444 group. Typically, reasoning statements involved descriptions of the function or purpose of a

445 certain feature in relation to a specific environmental constraint.

446 The drawings and notecards for sixteen student groups were analyzed using the design

447 argument framework described. The first and third author collaborated on this analysis, reaching

448 agreement on coding through continuous negotiation until agreement was reached. The third 
449 author was not part of the team who administered the PBL unit to students, so was not biased as

450 to how students generated drawn arguments. The analysis focused only on the design solutions

451 generated for the markle organism, as these solutions required the consideration of

452 environmental constraint information collected through student activity and markle traps did not.

453 Thus, the trap designs are not discussed further here. The use of environmental constraint

454 information as evidence required students to build on their understanding of the genetic and

455 environmental concepts taught during the station activities at the beginning of the PBL unit. The

456 analysis quantitatively analyzed the presence and frequency of various combinations of claim,

457 evidence, and reasoning components present in each groups'set of drawings and notecards. The

458 analysis of groups' drawings included counting drawn and written components present and their

459 nature, while the notecards were analyzed for the presence of various combinations of written

460 argument components. Our focus for this analysis was to describe the variation of argument

461 structures produced by students who engaged in the Markle PBL unit. We did not engage in an

462 evaluation of the quality of these elements, as our research focus pertained more to

463 understanding what kinds of elements emerged in students' arguments when afforded

464 opportunities to draw them instead of just writing text for them. Following this analysis, we

465 identified several groups to further describe using small case studies (Stake, 2006) to

466 demonstrate and compare some of the variations in the design solutions generated.

467

468

469

470

471 interventions have been developed to improve genetics understanding in elementary school

472 students (Duncan et al., 2009), we first determined if students engaged in a genetics PBL 
473 demonstrated learning gains, particularly gains in traditionally difficult to understand genetics

474 concepts. To assess changes in genetics understanding, specifically the relationship of genotype

475 to phenotype and the nature of genes, students $(n=67)$ completed pre and posttest items.

476 Performance on the both the pretest and posttest was normally distributed. First, we conducted a

477 paired sample $t$-test to compare the pretest and posttest means. Responses on the posttest (mean

$478=3.05, S D=.45)$ were significantly different than responses on the pretest $($ mean $=2.68, S D=$

$479.66 ; t=-2.32, d f=19, p=.03$, Cohen's $d=.66)$. Next, we examined if student performance on

480 all three of the genetics test items improved between the pre and posttest. For the first two items,

481 Why do people look different from each other?; Why don't all people have the same hair color?

482 within-subjects paired $t$-tests revealed a statistically significant increase in conceptual

483 understanding from pretest to posttest (Question 1: pretest $M=2.89, S D=1.14$; posttest $M=$

$4843.25, S D=1.13 ; t(66)=-2.20, p=.03$, Cohen's $d=0.32$; Question 2: pretest $M=2.97, S D=$

4851.18 ; posttest $M=3.35, S D=1.06 ; t(66)=-2.14, p=.04$, Cohen's $d=0.34$; Figure 1). Using a

486 third within-subjects paired $t$-test, we did not observe a statistically significant difference in

487 students' understanding of the nature of genes between the pretest and posttest (Question 3:

488 pretest $M=2.22, S D=1.13$; posttest $M=2.17, S D=1.26 ; t(66)=0.26, \mathrm{p}=.80$, Cohen's $d=$

$489 \quad 0.04$; Figure 1) ${ }^{1}$.

\section{Place Figure 1 Here}

\footnotetext{
${ }^{1}$ We noted that second graders performed more poorly on the posttest for Question 3 than did other grade levels (Figure 2). However, when we omitted second graders' data from the analysis, there were still no statistically significant gains between pretest and posttest for Question 3.
} Figure 1 illustrates pretest and posttest scores for Question 3 with second graders included. 
Next, we sought to determine whether improvements in overall performance on the

492 genetics assessment differed for each grade level. We conducted paired samples $t$-tests

493 comparing pretest mean score and posttest mean score for each grade level $-1^{\text {st }}, 2^{\text {nd }}, 3^{\text {rd }}, 4^{\text {th }}$, and

$4945^{\text {th }}$. Scores improved from pretest to posttest for all grade levels, except for $2^{\text {nd }}$ grade. The only

495 significant difference from pretest to posttest was for $3^{\text {rd }}$ graders (mean at pretest $=2.57, S D=$

$496.74 ;$ mean at posttest $=3.08, S D=.64 ; t=-2.82, d f=16, p=.01 .$, Cohen's $d=.74$ ). (See Figure

497 2.)

Given our observation above that as a whole, students improved on their posttest scores on questions 1 and 2, but not 3 , we next sought to determine differences in change scores from pretest to posttest across the grade levels, first through fifth (Figure 2). For Questions 1 and 2, a one-way analysis of variance (ANOVA) revealed no statistically significant differences in score change (posttest score - pretest score) among the grade levels. For Question 1, on average all

503 students in each grade level demonstrated gains in conceptual understanding from pretest to 504 posttest (Figure 2). For Question 2, overall gains were seen for third-, fourth-, and fifth-grade 505 students, but not for first- and second-grade students (Figure 2). For Question 3, there was a 506 marginally significant difference in change scores across grade level $(F(4,62)=2.37, p=0.62)$.

507 Post-hoc analysis with Fisher's least significant difference test indicated that second graders

508 were different than all other grade levels. Specifically, second graders performed more poorly at 509 the posttest than at pretest for Question 3; whereas first and fourth graders demonstrated modest 510 improvement and third and fifth graders no improvement (Figure 2).

\section{Place Figure 2 Here} To determine whether or not this discrepancy was the result of differences in baseline 513 understanding, we compared pretest scores among all grade levels. Students did not perform 
514 differently at pretest on Questions 2 or 3. However we did observe a statistically significant

515 difference on pretest performance for Question $1(F(4,62)=4.70, p=0.00)$. Post-hoc analysis

516 with Fisher's least significant difference test indicated that fifth graders' pre-test scores $(M=$

$5173.17, S D=1.23)$ were statistically higher than all of the other students' scores (first grade, $(M=$

$5182.30, S D=1.23)$; second grade $(M=2.50, S D=1.22)$; third grade $(M=2.57, S D=1.17)$; fourth

519 grade, $(M=2.54, S D=0.97)$.

520 Characteristics of student-generated design solution arguments

521 Reviewing the products generated by student groups during the markle design activity

522 revealed interesting trends. Overall, the different groups were able to incorporate the

523 environmental constraint information in their designs of a markle. Across all groups, features

524 were included in each markle design that could be reasonably connected to the specific

525 environmental factoids each group received during the first part of the unit. Thus, at least

526 anecdotally, evidence exists that all student groups were able to process the environmental

527 constraint factoids and develop designs responsive to them. However, the analysis described here

528 does not include any inferred or anecdotal connections between students' designs and relevant

529 environmental constraints. The following analysis first focuses on general trends in explicit

530 elements, either drawn or written, included in the markle design presented to the other groups.

531 As these designs represent complete argument products emerging from the unit activities, they

532 were the primary unit of analysis. We expanded that unit to also include the notecards that were

533 prepared for the presentation in an effort to capture as many connections as possible being made

534 by students between design features (claims), environmental constraints (evidence), and the

535 relevant functions of those features (reasoning). 
The analysis of all groups' arguments involved both the actual drawing presented and the presentation notecards prepared by the students. Table 5 provides an overview of how student

538 groups incorporated different argument elements in the drawing they presented. Recall, two

539 primary aims of this study were to investigate whether elementary students are able to coordinate

540 claims, evidence, and reasoning and how the creation of illustrated arguments relate to this

541 ability. All groups developed a drawn design, so at minimum, they all produced a drawn claim.

542 However, a claim alone is not an argument. Six out of 16 groups (38\% of the groups) only

543 provided a drawn design/claim with no other supporting information, thus not providing an

544 argument in their final design solution. Three more groups only included written labels with their

545 drawings to highlight certain features. This means the majority, approximately $56 \%$, of the

546 groups did not provide an argument in their illustrated design solutions. The remaining groups

547 did incorporate explicitly some combination of argument elements in their presented design

548 solution. Only one group explicitly incorporated constraint information through drawing, using

549 illustrated evidence about the environment to support markle features they developed. This group

550 also included written reasoning statements to describe the functions of their design relative to the

551 environment. Another group only included written reasoning statements with their drawing that

552 described the functions of specific design features. Finally, five student groups included several

553 written statements on their presented designs that incorporated combinations of the different

554 argument elements, with some statements including both evidence and reasoning and some with

555 only reasoning included. It is worth noting that all of the illustrated arguments included text on

556 the illustration, with the exception of a single drawn claim plus drawn evidence argument.

557 However, even in this case, the group included a written reasoning statement on their illustration.

558 We describe this group in more detail as a case study later. 


\begin{tabular}{clcc} 
& CER Elements in Drawings & \# of Groups & \% of Groups \\
\hline $\begin{array}{c}\text { No illustrated } \\
\text { argument present }\end{array}$ & Drawn C Only & 6 & $38 \%$ \\
& Drawn C with Written Label & 3 & $19 \%$ \\
\hline & Drawn C with Drawn E \& & 1 & $6 \%$ \\
$\begin{array}{c}\text { Illustrated } \\
\text { argument present }\end{array}$ & Drawn C with Written C, E \& R & 5 & $31 \%$ \\
& elements & & $6 \%$ \\
& Drawn C with Written R Only & 1 & \\
\hline
\end{tabular}

561 Note: $\mathrm{C}=$ claim, $\mathrm{E}=$ evidence, $\mathrm{R}=$ reasoning.

The analysis of the notecards provided a more complex view of how each group

563 incorporated different elements of evidence and reasoning in the final design solution they

564 presented. Table 6 provides a quantitative description of the different combinations of argument

565 components present on the notecards for each group. Each statement on a group's notecard was

566 analyzed individually for argument components. In some instances, pairs of sentences were

567 analyzed together as they comprised one coherent unit of argument elements. Although more

568 complex in the distribution of combinations, broad trends are readily apparent in the table. First,

569 the majority of the statements students wrote on their notecards emphasized connections between

570 certain features of their markle design (claim) and their function (reasoning). Yet, it is notable

571 that student groups were more explicit in being sure to call out specific environmental constraint

572 evidence to support the features of their markle design for their presentation, either separately or 
573 in combination with elements of reasoning, rather than paired with their claim. Thus, in the

574 overall analysis of the groups' final design solutions, student groups' ability to incorporate

575 argument components was more prevalent in their written notations as opposed to in their

576 illustrated forms. Nevertheless, it is important to note that the illustration provided a point from

577 which claims, evidence, and reasoning could emerge.

578 Table 6. Quantitative Comparison of CER Elements in Notecard Statements

579

\begin{tabular}{llllll}
\hline Group & C Only & E Only & C + E & C + R & C+E+R \\
\hline
\end{tabular}

\begin{tabular}{|c|c|c|c|c|c|}
\hline $\mathrm{A}$ & & & & 6 & \\
\hline B & & & & 1 & 2 \\
\hline $\mathrm{C}$ & 1 & & & 4 & 2 \\
\hline D & & & & 2 & 3 \\
\hline $\mathrm{E}$ & & & & 8 & \\
\hline $\mathrm{F}$ & 1 & 1 & & 5 & 1 \\
\hline $\mathrm{G}$ & & & 2 & 1 & 1 \\
\hline $\mathrm{H}$ & 4 & & & 1 & 2 \\
\hline I & & 2 & 3 & 1 & 1 \\
\hline $\mathrm{J}$ & 1 & 2 & 1 & 5 & \\
\hline $\mathrm{K}$ & & & & 7 & 2 \\
\hline $\mathrm{L}$ & & & & & \\
\hline $\mathrm{M}$ & & & & & \\
\hline $\mathrm{N}$ & & & & & \\
\hline $\mathrm{O}$ & 2 & & & 2 & 2 \\
\hline $\mathrm{P}$ & & & 1 & 6 & 1 \\
\hline
\end{tabular}




\section{Variations among student groups: Four cases}

To provide further insight into the kinds of design solutions developed by elementary

583 students in this activity, we provide a more detailed description of four student groups, with each

584 group serving as a case for this part of the analysis. The four cases were selected to represent

585 unique solutions to help the reader see the nature of the design solutions presented. Table 7

586 provides pictures of each group's markle design and other relevant information.

Group E: A case of drawn evidence. Only one group out of 16 explicitly drew design constraints, or evidence as conceptualized here. The environment constraints related to the presence of lakes and "tall trees" in the markle's environment are prominent elements in Group

590 E's drawing. The few written statements included in the group's drawing focus only on

591 reasoning elements, describing the function of certain features (e.g., "Claws for digging and

592 killing prey", "Wings for flying and propelling through water"). Interestingly, though they were

593 the only group to draw evidence, they were also one of the only groups that did not include

594 evidence in their written notecard. Example statements from their notecards include a string of

595 several claim and reasoning combinations: "The wings are to fly and propel through water. The

596 eyes for night vision. Fangs for biting prey. Gills for swimming. Claws for killing prey and

597 digging wandering around. Changing color of fur."

598 This group provided one of the largest amounts of written argument combinations on its

599 notecard as well. The group composition was relatively equal in its distribution across grade

600 levels, with two first graders, and one student from every other grade level, second through fifth. 
Table 7. Comparison of Student Group Cases

\section{Drawing}

Group E- Drawn Evidence

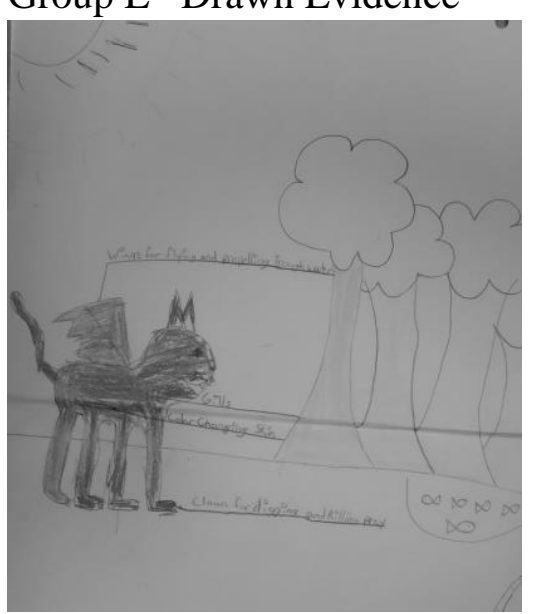

\section{Environmental Constraints/Evidence}

- Your region has large cliff faces. Birds like 1 Drawn C the nest high on these cliff faces, and markles 2 Drawn $\mathrm{E}$ love to eat their eggs.

- All of the lakes in your region of Planet Markle contain large markle-eating sea monsters.

- Giant snakes that like to eat markles live in your region. These giant snakes can't see markles that are hidden well.

- Your region is susceptible to tidal waves and markles are at risk for drowning without certain adaptations.

- Your region is full of tall trees

Group A - Younger Group with Large Amount of Reasoning on Drawing

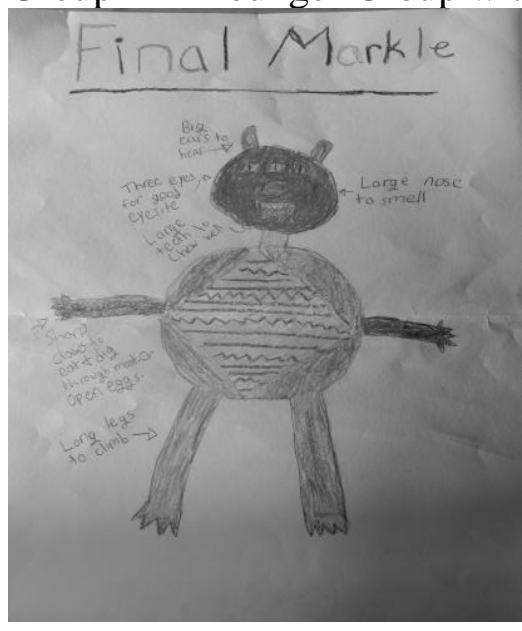

- Your region is very cold

- Your region is very snowy

- Your region is full of tall trees

- Your region of Planet Markle has large cliff faces. Birds like to nest high on these cliff faces, and markles love to eat their eggs

- Your region of Planet Markle is very dark and it is difficult to find food using eyesight alone
CER Elements Drawing

3 Written $\mathrm{C}+\mathrm{R}$

\section{CER Elements - Students' Notecards \\ Grade \\ Level}

$8 \mathrm{C}+\mathrm{R}$ Statements $1^{\text {st }}-2$

$2^{\text {nd }}-1$

$3^{\text {rd }}-1$

$4^{\text {th }}-1$

$5^{\text {th }}-1$ 


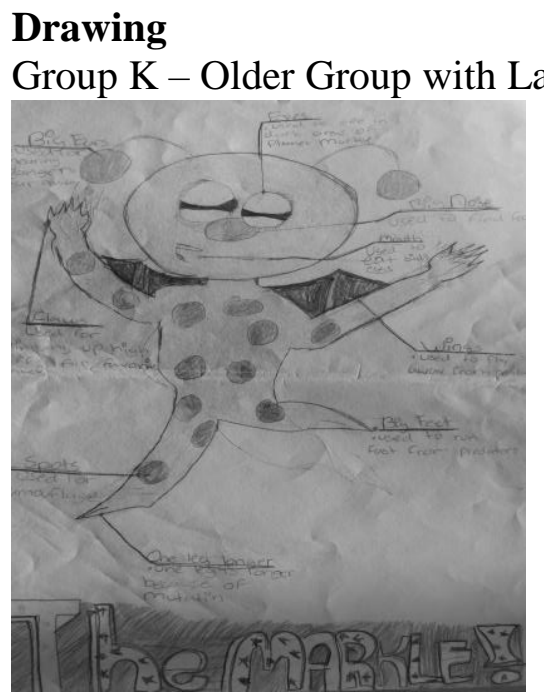

\section{Constraints}

Amount of Reasoning on Drawing

- Your region is very dark and it is difficult to find food using eyesight alone

- Your region has large cliff faces. Birds like the nest high on these cliff faces, and markles love to eat their eggs.

- Your region has very few trees and rives full of fish

- Your region is in a desert with lots of quicksand

- Your region produces gamma rays that cause mutations in your markles that change their fur color

\section{CER-Drawing}

1 Drawn C 3 Written $\mathrm{C}+\mathrm{E}+\mathrm{R}$

6 Written $\mathrm{C}+\mathrm{R}$
Group G - Only Claim Drawn, Notable Written Evidence

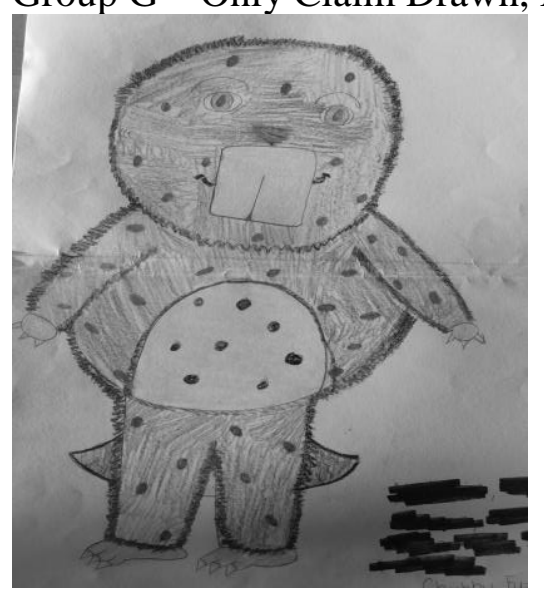
love to eat their eggs. certain adaptations dams
- Your region has large cliff faces. Birds like 1 Drawn Claim the nest high on these cliff faces, and markles

- Your region if full of tall trees

- Your region is susceptible to tidal waves and markles are at risk for drowning without

- Your region contains lots of large beaver-like animals that cut down all of the trees to build

- Aliens from Planet Narp want the markles spotted fur.
$2 \mathrm{C}+\mathrm{E}$ Statement $1^{\text {st }}-1$

$1 \mathrm{C}+\mathrm{R}$ Statements $2^{\text {nd }}-2$

$1 \mathrm{C}+\mathrm{E}+\mathrm{R} \quad 3^{\text {rd }}-1$

Statement $\quad 4^{\text {th }}-1$

$5^{\text {th }}-2$

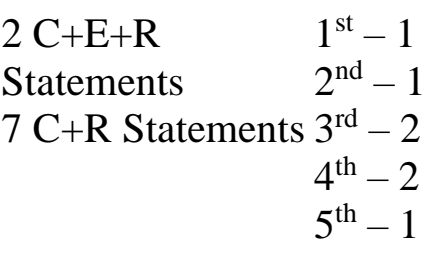


Groups A \& K: The impact of age. Two other groups who both incorporated a larger number of reasoning statements in their drawing and notecards also provide a contrast in group

3 structure. Group A was markedly younger, with most members being in third grade or below.

4 They provided reasoning elements explaining the functions of each design feature they

5 highlighted in their drawing for a total of six, such as "Long legs to climb," (Written C+R) and

6 "Three eyes for good eyesight." (Written C+R) Most of these statements were repeated in their 7 presentation notecards.

8 Similarly, another group, Group K, provided a slightly larger amount of statements with 9 argument components on both their drawing and notecards. The age composition of this group

10 skewed slightly older as the majority of student members were in third grade or older. A notable

11 difference in the statements provided by this group involves their use of explicit references to 12 environmental constraints as evidence to support certain design features. On their drawing, the 13 group wrote statements including, "Claws used for climbing up high cliffs for favorite snack."

14 (Written $\mathrm{C}+\mathrm{E}+\mathrm{R}$ ) Similar statements were included on the group's notecards, such as, "Eyes:

15 These eyes are used to see in the dark areas of Planet Markle." (Written C+E+R) Although this

16 group did incorporate evidence in some of their statements, the majority of their written

17 statements involved only claim and reasoning elements. Thus, both groups, although comprised

18 of different age concentrations, demonstrate the ability to incorporate relevant argument

19 components in explaining their design solutions. The presence of more explicit references to

20 constraint information as evidence from the older group of students does suggest a

21 developmental emergence of understanding the need to coordinate multiple argument

22 components. 
Group G: Illustrations with no written text. We also analyzed another case where the

24 student group only provided a drawing for their final design solution with no written elements

25 present. Although they did not add any further detail to their drawing, they did provide

26 statements comprised of argument elements on their notecards, although limited to only four.

27 While smaller in amount of statements, the bulk of this group's writing could be considered

28 higher quality due to explicitly incorporating evidence from constraints to defend particular

29 features. Examples of such statements include: "Our markle has fins and gills because our

30 markle is at risk of drowning," (Written $\mathrm{C}+\mathrm{E}$ ) and "Our markle has claws because our markle

31 uses his claws to climb up cliffs to get bird eggs." (Written $\mathrm{C}+\mathrm{E}+\mathrm{R}$ )

32 The first example provided shows an example of a statement that includes only claim and

33 evidence elements without text describing their reasoning involving function. In comparison, the

34 second statement shows how this group coordinated evidence and reasoning elements for a

35 specific design feature: an ideal argument. As described in Table 7, the grade composition of this

36 group also tended towards being older with over half of the students being in third grade or

37 higher. Indeed, out of the nine groups that only provided a drawing (some with labels) for their

38 design solutions, six of them did incorporate explicit references to constraint evidence in their

39 notecards in a similar manner as the Group G. All six of these groups shared another similarity in

40 that their grade level compositions tended to be a majority of older students in third grade or

41 above. Of the groups that did not provide explicit reference to constraint evidence in the

42 notecards, most of them were more balanced with greater numbers of students in lower grades.

\section{Discussion}


Although genetics is typically taught to older students (Duncan et al., 2009), we observed that the elementary-aged students participating in this PBL unit increased their understanding of

47 genetics principles that are typically misunderstood. Third graders experienced significant gains

48 in their overall genetics understanding after participation in the PBL. More specifically, we noted

49 that students' understanding of the deterministic nature of genes were most likely to improve.

50 Students' understanding of the nature of genes and genetic material did not improve, which may

51 indicate that this is a particularly difficult concept for young students to grasp and likely requires

52 additional instruction beyond what was provided at the unit stations. Regardless of grade level,

53 following the PBL unit, students were more likely to explicitly reference genes, inheritance, or

54 genetic material when asked why people look different from one another. When asked about hair

55 color, however, there was a variation in improvements in conceptual knowledge across grades.

56 Specifically, first graders showed a slight decrease in performance from pretest to posttest and

57 second graders had no change in their performance. The older students all improved their scores

58 on this item. This may indicate that this was a slightly harder question for the younger students,

59 or that the students still required some additional scaffolds to fully understand this concept. The

60 cognitive demands of the questions' open-ended nature may have posed differential demands

61 across development as well. These findings align with prior work that suggests genetics content

62 may be particularly difficult for students, but can be best scaffolded, even for younger children

63 with PBL or inquiry instruction (Araz \& Sungur, 2007; Henderson \& Maguire, 2000; Shaw, Van

64 Horne, Zhang, \& Boughman, 2008; Smith \& Williams, 2007; Venville, Gribble, \& Donovan, $652005)$

Interpreting changes in students' understanding of genes is more difficult, given our

67 findings. Overall, students were no more likely to acknowledge DNA or inheritance in their 
68 description of genes following the PBL unit. First and fourth graders demonstrated modest

69 improvements, but we observed no difference in understanding for the third and fifth graders.

70 Interestingly, second graders were less likely to mention heritability following the unit. Notably,

71 this was the case for all second graders rather than being driven by an outlier. Additionally,

72 second graders answered this item similarly to students in other grades before the PBL unit.

73 Since the nature of genes is a common misconception, and since this large drop was only seen

74 among one group of students, it may be the case that instruction outside of the PBL in the second

75 graders' normal classes may have resulted in the presence of a misconception or overemphasis

76 on the connection between genes and traits rather than on heritability. Unfortunately, the

77 research team is unaware of and unsure about what such disruptive instruction may have been.

78 Despite anomalous findings with regard to students' understanding of what genes are,

79 improvements in understanding inheritance following the unit are promising. Even very young

80 students may be capable of learning genetics concepts. We take this as evidence for genetics

81 learning progressions starting earlier than late elementary or middle school. We also take the

82 shift in second grade TAG students - who were engaged in accelerated third grade genetics

83 curriculum outside of the unit - as evidence that students' genetics misconceptions require

84 specific sensitivity in early years.

85 Arguments constructed in a PBL unit

86 One aim of this work was to determine if elementary school students are capable of

87 employing reasoning to support claims with evidence in their illustrated products and without

88 explicit instruction about constructing arguments using evidence and reasoning. Students'

89 illustrations and presentation notes as part of a capstone assignment following the PBL unit

90 explicitly incorporated major components of arguments-claims, evidence, and reasoning. 
91 Mixed age groups of high achieving and gifted students successfully made claims about their

92 illustrated design solutions and used evidence to support these claims, all without scaffolding or

93 instruction specific to argument construction. The nature and quantity of different combinations

94 of claims, evidence, and reasoning elements varied noticeably across groups in their drawings

95 and written notation.

96 The variation noted across these groups offers further demonstration of a developmental

97 trajectory for students' ability to engage in the coordination activities necessary for the

98 development of scientific arguments argued for by others (Kuhn, 1991, 2005). For learners to

99 improve in their ability to construct higher quality arguments, they must also improve their

100 ability to evaluate their knowledge products using metacognitive abilities (Garcia-Mila \&

101 Andersen, 2007). Looking across the groups described in Table 6, those that had a larger share of

102 older students produced richer collections of drawn and written argument components. Thus, our

103 findings agree with other scholars who have argued for the importance of developing

104 metacognitive abilities in complement to enhancing their ability to learn through argumentation

105 (Garcia-Mila \& Andersen, 2007; Kuhn, 2005). Following this line of thinking, incorporating

106 instructional elements that afforded students opportunities to explicitly reflect on their design

107 solutions could potentially have increased the groups' explicit coordination of their Markles to

108 the environmental constraints they had. Incorporation of such intentional scaffolding has been

109 shown to be helpful in such learning (Felton, 2004; Zohar \& Nemet, 2002).

110 A premise for the current study contends that by allowing students to draw their design

111 solutions, the difference in expectations would facilitate a more accessible venue for elementary

112 students to create high quality arguments. The results developed here do not offer resounding

113 support for this premise in that only one group actually illustrated elements of evidence in its 
114 final solution. However, several other groups used their drawings to then generate statements

115 that did incorporate both evidence and reasoning components to explain particular design

116 features. Beyond the drawn design solutions, the presentation notecards also offer further

117 demonstration of student groups explicitly incorporating elements of evidence and reasoning to

118 argue for the design solution they developed. Although students did not express them through

119 drawing, the mode of expression did provide a vehicle for them to incorporate argument

120 components in a coherent manner. Therefore, we agree with scholars who assert that drawings

121 are a valid form for having students express their understanding of complex events (Bowker,

122 2007; Chang, 2012). The current study adds further texture to this notion by demonstrating that

123 although students may not fully express themselves using this mode of expression, drawing can

124 also facilitate students' use of writing in a more meaningful manner. The student groups were

125 prompted through their drawings to explain at minimum their reasoning for including certain

126 design features as well as evidence (environmental constraints) to support their inclusion through

127 written text, both on the image and in their notecards. The use of drawings in the science

128 classroom can assist in helping students express complex ideas through imagery, but also provide

129 an expressive anchor to ground their writing in as well. Yet, the use of drawings does still

130 present challenges in the science classroom.

131 For students, the word "argument" may have a negative connotation, which can influence

132 how students engage in discourse (McNeill, 2009). Rather than ask students to create an

133 argument, we asked students to create an illustrated design solution to assess the presence of

134 claims, evidence, and reasoning. Even though this task differs from typical argument

135 construction tasks, our finding that students have difficulties explicitly connecting evidence to

136 claims is consistent with prior research analyzing students' written arguments (Berland \& Reiser, 
137 2009; McNeill, 2011; Ryu \& Sandoval, 2012). For example, prior to instruction in

138 argumentation, Ryu and Sandoval (2012) rate third- and fourth-grade students' written

139 arguments as having little-to-no evidence cited and lacking explicit justifications. These

140 challenges persisted, although alleviated somewhat, after instruction. In the current study, we

141 also noted students did not explicitly include appropriate evidence in the majority of argument

142 statements they constructed in writing. The persistence of these student challenges provides

143 further support for the emphasis on the scientific and engineering practices identified in the

144 NGSS and state adopted variations of them. Having students engage in these practices is not

145 merely enough, rather we must also help them to understand the nature and role of these

146 practices in science (Ford, 2008; 2015). In light of the results of this study and others noted

147 previously (McNeill, 2011; Ryu \& Sandoval, 2012; Venville \& Dawson, 2012), we agree with

148 this premise and the importance of incorporating instruction in science classrooms that addresses

149 the practices and their constitutive elements explicitly. Further, if we endeavor to help students

150 gain better understanding and proficiency with arguing from evidence, science educators must

151 also be mindful to help students understand variations in the types of evidence necessary for

152 particular purposes and problems.

153 The instructional unit and related tasks involved in this study were framed using a PBL

154 approach. Often, PBL uses ill-structured problems to frame the entire unit and contextualize the 155 science content to be learned (Savery, 2015). However, the problems students engage in solving 156 are not always answered through empirical investigation. Rather, the end products for students

157 engaged in some PBL units are more aptly characterized as problem solutions. As such, students 158 must come to understand the difference between an empirical investigation and the development 159 of a designed problem solution (Berland, 2013; Householder \& Hailey, 2012; Leonard, 2005). 
160 To develop solutions to design problems, students must engage in the design process, which

161 includes empirical investigations to test prototypes, but also involves the development of

162 potential solutions that can be used to develop prototypes (Berland, 2013). In this study, the main

163 product of students' efforts reflects this first stage of the design process where they developed

164 markle organisms that could potentially survive in the environmental constraints they collected

165 through their factoid finding work at the beginning of the unit. We argue that in this stage of the

166 design process, material regarding constraints is the most plausible source for external

167 information that can be used to assess the appropriateness for a particular claim or design feature.

168 This information is similar to analyzed data collected during an investigation serving as evidence

169 to support a claim answering the question guiding the investigation. These differences in the

170 nature of information needed for evidence for particular types of tasks can also help explain why

171 we did not see as many evidentiary elements incorporated into student groups' drawn and written

172 markle solutions.

173 The different markle designs from all groups demonstrated that students were mindful of

174 the environmental constraint information they collected, as the features and reasoning statements

175 provided by groups often implied, if not explicitly mentioned, one of the design constraints. It is

176 reasonable to think that if these students had been provided explicit instruction in what the

177 components of a high quality arguments included, particularly in a design solution context, then

178 more groups would have provided explicit connections. The results of this study are promising

179 when interpreted to show that even without such support and guidance intentionally embedded in

180 the PBL unit, several groups did seek out those conceptual connections in the solutions they

181 presented. We concur with other scholars who have also drawn attention to the importance of

182 incorporating explicit teaching in science classrooms that focuses on the unique characteristics 
183 and elements of design problems and having students engage in those activities in meaningful

184 ways to help them understand the differences compared to scientific investigations (Berland,

185 2013; Householder \& Hailey, 2012).

186 Considerations for PBL use

187 The findings of this study can also inform science teachers who work on implementing

188 PBL instruction in their classrooms. As seen in this study, PBL units do create contexts for

189 students to learn complex science content, such as genetics and evolution, as well as getting them

190 to engage in multiple science and engineering practices, such as arguing from evidence. Indeed,

191 these contexts offer teachers opportunities to have students make personal, affective connections

192 with the content they are trying to teach and provide shared experiences of students' participation

193 in those practices, creating space for students to learn from each other. Yet, to engender these

194 types of learning events through PBL, teachers must be mindful of providing explicit instruction

195 in the fundamental nature of the practices. PBL can be used to frame students' engagement in a

196 practice, but to gain a solid understanding of the practice students must also learn about its

197 elements (Ford, 2008). Thus, with respect to the PBL unit in this study, students could have

198 received instruction about what elements are necessary for a high quality argument once they had

199 completed station activity focusing on genetics content and collection of environmental

200 constraint information. Further, this unit could have been enhanced by also helping students

201 understand the broad goal as a design task and the distinct criteria for what claims, evidence, and

202 reasoning entail in such contexts. Explicitly distinguishing the types of argument producing

203 activities (e.g., investigations and design problems) would also enhance students understanding

204 of the variations of activities that comprise the scientific enterprise. 
Limitations \& future directions

208 Despite the benefits of our findings, these are somewhat exploratory and not without

209 limitation. Understanding how illustrations serve as points of assessment and intervention in

210 young children's argumentation skills should be expanded in future work by employing

211 experimental design and adding instructional scaffolds, such as peer reviews or feedback on

212 students' labels of claim, evidence, and reasoning in sample illustrations. Because we did not

213 include any scaffolds or probes of student thinking (e.g., peer review or interviews) in this study,

214 our current findings are limited to coding decisions based on our interpretations. While we

215 expect including additional probes would further validate our findings, we were effortful in our

216 current design in order to observe young students' abilities in constructing arguments without the

217 interference of any instruction. Our findings are further limited in their generalization to a broad

218 population. We examined outcomes with a mixed group of talented-and-gifted and able learner

219 students from one school site. These students participated because they were free to engage in

220 flexible curriculum while other students worked to develop proficiency in math and literacy

221 during a daily enrichment/instructional focus period at the school site. The research questions

222 considered here should be further explored in other populations of students.

\section{Conclusion}

224 Argumentation is an essential part of both science practice and education, but is

225 challenging for students to learn. This work demonstrated that a different type of task, the

226 creation of illustrated fictitious aliens, when assessed as an argument, shared many features and

227 challenges seen when students engage in typical classroom argumentation tasks. The work here

228 proposes an additional method for teaching and studying elementary school students' 
229 argumentation practices and provides evidence of its utility for gaining new insights into how

230 children learn and understand arguments, particularly in a design setting. Students were able to

231 demonstrate success in gaining difficult genetics content knowledge as well as in preparing

232 arguments with, at minimum, two components of well-constructed arguments, and in most cases

233 providing a claim supported by reasoning. This work is informative for understanding student

234 abilities, the potential of PBL, and considerations for its use.

235

236

237

238

239

240

241

242

243 


\section{References}

245 Allen, D. E., Duch, B. J., \& Groh, S. E. (1996). The power of problem-based learning in teaching introductory science courses. New Directions for Teaching and Learning, 1996(68), 43-

248 Araz, G., \& Sungur, S. (2007). Effectiveness of problem-based learning on academic performance in genetics. Biochemistry and Molecular Biology Education, 35(6), 448-

Baser, D., Ozden, M. Y., \& Karaarslan, H. (2017). Collaborative project-based learning: an 451.

Bell, S. (2010). Project-Based Learning for the 21st Century: Skills for the Future. The Clearing House: A Journal of Educational Strategies, Issues and Ideas, 83(2), 39-43. https://doi.org/10.1080/00098650903505415

Belland, B. R., Glazewski, K. D., \& Richardson, J. C. (2011). Problem-based learning and argumentation: Testing a scaffolding framework to support middle school students’ creation of evidence-based arguments. Instructional Science, 39(5), 667-694.

261 Belland, B. R. (2010). Portraits of middle school students constructing evidence-based arguments during problem-based learning: The impact of computer-based scaffolds. Educational technology research and Development, 58(3), 285-309. 
Berland, L. K., \& Reiser, B. J. (2009). Making sense of argumentation and explanation. Science Education, 93(1), 26-55.

Berland, L. K., Schwarz, C. V., Krist, C., Kenyon, L., Lo, A. S., \& Reiser, B. J. (2015). Epistemologies in practice: Making scientific practices meaningful for students. Journal of Research in Science Teaching.

Bowker, R. (2007). Children's perceptions and learning about tropical rainforests: An analysis of their drawings. Environmental Education Research, 13(1), 75-96.

Brooks, M. (2009). Drawing, visualisation and young children's exploration of "big ideas". International Journal of Science Education, 31(3), 319-341. doi:10.1080/09500690802595771

Chang, N. (2012). What are the roles that children's drawings play in inquiry of science concepts?. Early child development and care, 182(5), 621-637.

Dentzau, M. (in press). Students' changing mental models of the longleaf pine ecosystem after involvement in an outdoor environmental education program. Southeastern Naturalist.

Dochy, F., Segers, M., Van den Bossche, P., \& Gijbels, D. (2003). Effects of problem-based learning: a meta-analysis. Learning and Instruction, 13(5), 533-568. http://doi.org/10.1016/S0959-4752(02)00025-7

Duncan, R. G., \& Reiser, B. J. (2007). Reasoning across ontologically distinct levels: Students' understandings of molecular genetics. Journal of Research in Science Teaching, 44(7), 938-959. doi: 10.1002/tea.20186

Duncan, R. G., Rogat, A. D., \& Yarden, A. (2009). A learning progression for deepening students' understandings of modern genetics across the 5th-10th grades. Journal of Research in Science Teaching, 46(6), 655-674. doi:10.1002/tea.20312 
Elmesky, R. (2013). Building capacity in understanding foundational biology concepts: A K-12 learning progression in genetics informed by research on children's thinking and learning. Research in Science Education, 43(3), 1155-1175. doi:10.1007/s11165-012-9286-1

292 Felton, M. K. (2004). The development of discourse strategies in adolescent argumentation. Cognitive Development, 19(1), 35-52. http://doi.org/10.1016/j.cogdev.2003.09.001

294 Ferreira, M. \& Trudel, A. R. (2012). The Impact of Problem-Based Learning (PBL) on Student Attitudes Toward Science, Problem-Solving Skills, and Sense of Community in the Classroom. Journal of Classroom Interaction, 47(1), 23-30.

Ford, M. (2008). Disciplinary authority and accountability in scientific practice and learning. Science Education, 92(3), 404-423.

Ford, M. (2015). Educational implications of choosing "Practice" to describe science in the Next Generation Science Standards. Science Education, 99(6), 1041-1048.

Gallagher, S. A., Stepien, W. J., Sher, B. T., \& Workman, D. (1995). Implementing problembased learning in science classrooms. School Science and Mathematics, 95(3), 136-146. doi:10.1111/j.1949-8594.1995.tb15748.x

Georgia Department of Education. (2015). Georgia performance standards. Retrieved from https://www.georgiastandards.org.

Grooms, J., Enderle, P., \& Sampson, V. (2015). Coordinating Scientific Argumentation and the Next Generation Science Standards through Argument Driven Inquiry. Science Educator, inheritance. Social Science \& Medicine, 50(2), 293-301. 
311 Hmelo-Silver, C. E. (2004). Problem-Based Learning: What and How Do Students Learn?

312 Educational Psychology Review, 16(3), 235-266. http://doi.org/10.1023/B:EDPR.0000034022.16470.f3

314 Householder, D. L., \& Hailey, C. E. (2012). Incorporating engineering design challenges into 315 STEM courses.

316 Kereluik, K., Mishra, P., Fahnoe, C., \& Terry, L. (2013). What knowledge is of most worth. Journal of Digital Learning in Teacher Education, 29(4), 127-140. doi:10.1080/21532974.2013.10784716

Kolodner, J. L., Camp, P. J., Crismond, D., Fasse, B., Gray, J., Holbrook, J., ... Ryan, M. (2003). Problem-Based Learning Meets Case-Based Reasoning in the Middle-School Science Classroom: Putting Learning by Design(tm) Into Practice. Journal of the Learning Sciences, 12(4), 495-547. https://doi.org/10.1207/S15327809JLS1204_2

Kwon, K., Shin, S., Brush, T. A., Glazewski, K. D., Edelberg, T., Park, S. J., ... Alangari, H. (2018). Inquiry learning behaviors captured through screencasts in problem-based learning. Interactive Learning Environments, 26(6), 839-855. https://doi.org/10.1080/10494820.2017.1419496

Leonard, M. J. (2005). Examining tensions in a “design for science”' activity system: science versus engineering goals and knowledge. Tidskrift for Lararutbildning och Forskning [Journal of Research in Teacher Education], 3, 132-146. Hutchinson \& Co. Ltd. 
332 Manz, E. (2015). Representing student argumentation as functionally emergent from scientific activity. Review of Educational Research, 85(4), 553-590. doi:10.3102/0034654314558490

McNeill, K. L. (2009). Teachers' use of curriculum to support students in writing scientific arguments to explain phenomena. Science Education, 93(2), 233-268.

McNeill, K. L. (2011). Elementary students' views of explanation, argumentation, and evidence, and their abilities to construct arguments over the school year. Journal of Research in Science Teaching, 48(7), 793-823.

McNeill, K. L., \& Krajcik, J. (2006, April). Supporting students' construction of scientific explanation through generic versus context-specific written scaffolds. In Annual Meeting

344 McNeill, K. L., \& Berland, L. (2017). What is (or should be) scientific evidence use in k-12 classrooms?. Journal of Research in Science Teaching, 54(5), 672-689.

National Research Council. (1996). National Science Education Standards. Washington, D.C.: The National Academies Press.

National Research Council. (2007). Taking Science to School: Learning and Teaching Science in

351 National Research Council. (2012). A framework for K-12 science education: Practices, crosscutting concepts, and core ideas. Washington D.C.: The National Academies Press.

353 NGSS Lead States. (2013). Next Generation Science Standards: For States, By States. 
Osborne, J., Erduran, S., \& Simon, S. (2004). Enhancing the quality of argumentation in school science. Journal of Research in Science Teaching, 41(10), 994-1020. http://doi.org/10.1002/tea.20035

Ryu, S., \& Sandoval, W. A. (2012). Improvements to elementary children's epistemic understanding from sustained argumentation. Science Education, 96(3), 488-526.

Sampson, V., \& Clark, D. B. (2008). Assessment of the ways students generate arguments in science education: Current perspectives and recommendations for future directions. Science Education, 92(3), 447-472. http://doi.org/10.1002/sce.20276

Sampson, V., Enderle, P., \& Grooms, J. (2013a). Argumentation in science education. The Science Teacher, 80(5), 30.

Sampson, V., Enderle, P., Grooms, J., \& Witte, S. (2013b). Writing to learn by learning to write during the school science laboratory: Helping middle and high school students develop argumentative writing skills as they learn core ideas. Science Education, 97(5), 643-670. http://doi.org/10.1002/sce.21069

Savery, J. R. (2015). Overview of problem-based learning: Definitions and distinctions. In Walker, A., Leary, H., Hmelo-Silver, C., \& Ertmer, P.A. (Eds.), Essential readings in problem-based learning: Exploring and extending the legacy of Howard S. Barrows (pp. 5-15). West Layfette, Indiana: Purdue University Press.

Shaw, K. R. M., Van Horne, K., Zhang, H., \& Boughman, J. (2008). Essay contest reveals misconceptions of high school students in genetics content. Genetics, 178(3), 1157-1168.

Smith, L. A., \& Williams, J. M. (2007). "It's the X and Y thing": Cross-sectional and longitudinal changes in children's understanding of genes. Research in Science Education, 37(4), 407422. doi:10.1007/s11165-006-9033-6 
378 Springer, K., \& Keil, F. C. (1989). On the development of biologically specific beliefs: The case of inheritance. Child Development, 60(3), 637-648.

Stake, R. E. (2006). Multiple case study analysis. New York: Guilford Press.

381 Thomas, G. V., \& Silk, A. M. (1990). An introduction to the psychology of children's drawings. New York University Press.

Venville, G., \& Dawson, V. (2012). The Art of Teaching Science: For middle and secondary school. Allen \& Unwin.

Venville, G., Gribble, S. J., \& Donovan, J. (2005). An exploration of young children's understandings of genetics concepts from ontological and epistemological perspectives. Science Education, 89(4), 614-633. doi:10.1002/sce.20061

Voogt, J., \& Roblin, N. P. (2012). A comparative analysis of international frameworks for 21st century competences: Implications for national curriculum policies. Journal of Curriculum Studies, 44(3), 299-321. doi:10.1080/00220272.2012.668938

Walker, A., Leary, H., Hmelo-Silver, C., \& Ertmer, P. A. (Eds.). (2015). Essential Readings in Problem-Based Learning: Exploring and Extending the Legacy of Howard S. Barrows. West Layfette, Indiana: Purdue University Press.

White, R., \& Gunstone, R. (1992). Prediction-observation-explanation. In Probing how does it achieve its effects? American Educational Research Journal, 48(5), 11571186. 


\section{Figure Captions}

412 Fig. 1 Mean scores and standard deviations on genetics understanding Questions $1-3$ at pretest and at posttest. Scores ranged from $0=$ no correct conceptual understanding to $4=$ mature conceptual understanding. * indicates differences in pretest and posttest scores are significant at the $p<.05$ level.

416

417 Fig. 2 Mean change scores from pretest to posttest and standard errors on genetics understanding 418 Questions $1-3$ across grades 1 through 5. * indicates differences in pretest and posttest scores are significant at the $p<.05$ level. 